\title{
Determination of Nitrogen Losses in the Sulfuric Acid Solution, Waste of the ${ }^{15} \mathrm{~N}$ Separation Plant
}

\begin{abstract}
CRISTINA MARCU*, DAMIAN AXENTE, CODRUTA VARODI
National Institute for Research and Development of Isotopic and Molecular Technologies, 67-103 Donat Str., 400293, Cluj-Napoca, România

The most used method for production of stable isotope ${ }^{15} \mathrm{~N}$ is based on the isotopic exchange ${ }^{15} \mathrm{~N} /{ }^{14} \mathrm{~N}$ in the nitrogen oxides-nitric acid solution system, known as Nitrox system. At the bottom of the packed separation column, the reflux is provided by total conversion of nitric acid into nitrogen oxides by reaction with sulfur dioxide, in a packed column type refluxer. The waste of $\mathrm{HNO}_{3}-\mathrm{SO}_{2}$ reaction is sulfuric acid, solution of 65$70 \%$, which is evacuated at the bottom of the nitrogen oxides refluxer. The magnitude of the nitrogen losses, as $\mathrm{NO}_{x}$ and/or $\mathrm{HNO}_{3}$ in the waste sulfuric acid, were determined by analysing the effluent sulfuric acid by spectrofotometric method with Nessler reagent.
\end{abstract}

Keywords: isotope separation, Nessler reagent, sulfuric acid, nitrogen losses

At INCDTIM Cluj-Napoca, the stable isotope ${ }^{15} \mathrm{~N}$ is produced at concentration of 99 at. $\%{ }^{15} \mathrm{~N}$ by isotopic exchange method ${ }^{15} \mathrm{~N} /{ }^{14} \mathrm{~N}$ in $\left(\mathrm{NO}, \mathrm{NO}_{2}\right)_{(\mathrm{g})}-\mathrm{HNO}_{3(\mathrm{~s})}$ system [1]:

$$
\left({ }^{15} \mathrm{NO}^{,}, \mathrm{NO}_{2}\right)_{(9)}+\mathrm{H}^{14} \mathrm{NO}_{3(s)} \leftrightarrow\left({ }^{14} \mathrm{NO},{ }^{14} \mathrm{NO}_{2}\right)_{(g)}+\mathrm{H}^{15} \mathrm{NO}_{3(s)}
$$

with a single stage separation factor: $\alpha=1.055$, for $10 \mathrm{M}$ $\mathrm{HNO}_{3}$ at $25^{\circ} \mathrm{C}$ and atmospheric pressure.

At the bottom of the packed separation column, nitric acid is total converted into nitrogen oxides by reaction with sulfur dioxide:

$$
\begin{aligned}
& 2 \mathrm{HNO}_{3}+3 \mathrm{SO}_{2}+2 \mathrm{H}_{2} \mathrm{O}=2 \mathrm{NO}+3 \mathrm{H}_{2} \mathrm{SO}_{4} \\
& 2 \mathrm{HNO}_{3}+\mathrm{SO}_{2}=2 \mathrm{NO}_{2}+\mathrm{H}_{2} \mathrm{SO}_{4}
\end{aligned}
$$

The nitrogen (enriched in ${ }^{15} \mathrm{~N}$ ) losses in the waste sulfuric acid should be as much as few ppm of feeding nitric acid in order to have an efficient operation of ${ }^{15} \mathrm{~N}$ separation plant. The magnitude of nitrogen losses indicates the operating mode of the nitrogen oxides refluxer.

Colorimetric determination of ammoniacal nitrogen from different sources: rainwater [2], slaughterhouse [3], urine [4], blood [5] etc. can be done with Nessler reagent (potassium tetraiodomercurate II). This reagent is used for solutions that contain low ammonia concentration $[6,7]$. Ammonia forms with Nessler reagent an yellow complex [8]:

$$
2\left[\mathrm{Hgl}_{4}\right] \mathrm{K}_{2}+\mathrm{NH}_{3}+3 \mathrm{KOH}=\mathrm{NH}_{2} \mathrm{IHg}_{2} \mathrm{O}+7 \mathrm{KI}+2 \mathrm{H}_{2} \mathrm{O}
$$
[9].

The colour intensity depends on the reagent composition

\section{Experimental part}

For determination of nitrogen from waste sulfuric acid solution the calibration line was obtained by using sulfuric acid solution with known nitrogen concentration. That sample was placed in a modified Kjendahl apparatus, potasium hydroxide was added to neutralize the acid, then Dewarda's alloy, and the apparatus was heated in $\mathrm{H}_{2}$ current for $15 \mathrm{~min}$. The gaseous mixture containing ammonia, was bubled in a flask with a known volume of $0.1 \mathrm{~N} \mathrm{H}_{2} \mathrm{SO}_{4}$.
To that solution was added $1 \mathrm{~mL}$ of alkaline solution ( $10 \mathrm{~g} \mathrm{NaOH}, 10 \mathrm{~g} \mathrm{Na}$ CO in $100 \mathrm{~mL}$ double distilled water) and $2 \mathrm{~mL}$ of Nessler reagent. The yellow colored compound immediately appeared and the absorbance of that sample was measured at $425 \mathrm{~nm}$ with UV-1800 Shimadzu spectrophotometer after 15 minutes. After plotting of the calibration line, the magnitude of nitrogen losses in the waste sulfuric acid have been determined.

The method requires a rigid control of the reaction conditions to prevent the turbidity of the solution [10].

\section{Results and discussions}

The calibration line (Fig.1) was obtained by using samples with known nitrogen content: $0.82 \times 10^{-6} ; 1.64 \mathrm{x}$ $10^{-6} ; 2.46 \times 10^{-6}$ and $3.28 \times 10^{-6} \mathrm{~g} \mathrm{~N}$, obtained with $0.5 ; 1 ; 1.5$ and $2 \mathrm{~mL}$ of $\mathrm{NaNO}_{3}$ solution of $1.64 \times 10^{-6} \mathrm{~g} \mathrm{~N} / \mathrm{mL}$.

The absorbance of the waste sulfuric acid samples was determined and the corresponding nitrogen concentrations were read from the calibration line.

Knowing that the ${ }^{15} \mathrm{~N}$ separation plant is fed with 60 moles of $\mathrm{HNO} / \mathrm{h}$, the nitrogen losses, calculated in $\mathrm{ppm}$ of the nitric acid flow, are presented (Table 1).

All waste sulfuric acid samples presented in Table 1 contain nitrogen (enriched in ${ }^{15} \mathrm{~N}$ ) showing an improper operation mode of the refluxer.

$$
\begin{aligned}
& y=0.094+0.02659 x \\
& R^{2}=0.92686
\end{aligned}
$$

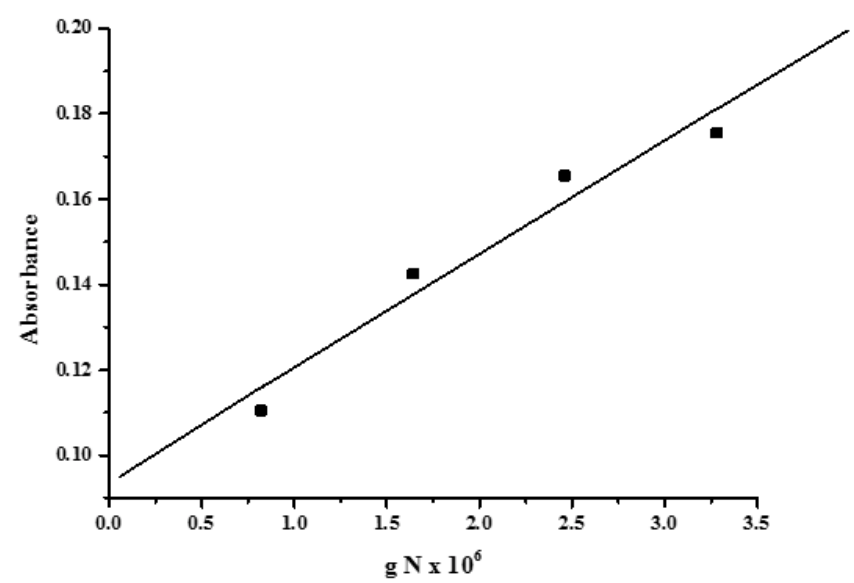

Fig.1 Calibration line 


\begin{tabular}{|c|c|c|c|}
\hline $\begin{array}{c}\text { Number of } \\
\text { Sample } \\
\left(\mathrm{H}_{2} \mathrm{SO}_{4}\right)\end{array}$ & Absorbance & $\begin{array}{c}\text { Nitrogen } \\
\text { losses } \mathbf{x} \text { 10 } \\
(\mathrm{g})\end{array}$ & $\begin{array}{c}\text { Nitrogen losses } \\
(\mathrm{ppm})\end{array}$ \\
\hline 1 & 0.1370 & 1.620 & 5.78 \\
\hline 2 & 0.1505 & 2.125 & 7.58 \\
\hline 3 & 0.0945 & 0.019 & 0.06 \\
\hline 4 & 0.1825 & 3.328 & 11.88 \\
\hline
\end{tabular}

Table 1

NITROGEN LOSSES IN SULFURIC ACID

SAMPLES, WASTE OF ${ }^{15} \mathrm{~N}$ SEPARATION

PLANT

\section{Conclusions}

Any loss of nitrogen (enriched in ${ }^{15} \mathrm{~N}$ ) is an additional, uncontrolled production that diminishes the normal production of ${ }^{15} \mathrm{~N}$ separation plant, indicating an improper operation of the nitrogen oxides refluxer.

Acknowledgments: The research leading to these results has received the funding from the NUCLEU project: PN 18-03 0101 of the Romanian Research and Innovation Ministry

\section{References}

1.AXENTE D., ABRUDEAN M., BLDEA A., Separarea izotopilor ${ }^{15} \mathrm{~N}$, ${ }^{18} \mathrm{O}$, ${ }^{10} \mathrm{~B},{ }^{13} \mathrm{C}$ prin schimb izotopic, Casa Cartii de Stiinta, Cluj-Napoca, 1994, p. $125-146$

2.NIEDZIESLKI P., KURZYCA I., SIEPAK J ., „A new tool for inorganic nitrogen speciation study: Simultneous determination of ammonium ion, nitrite and nitrate by ion chromatography with post-column ammonium derivatization by Nessler reagent and diode-array detection in rain water samples, Anal Chim Acta, 577, nr. 2, 2006, p. 220-224
3.LIN Y.M., LI L. Y., HU J.W., HUANG X.F., ZHOU C, JIA M., LI Z.B., Photometric Determination of Ammonia Nitrogen in Slaughterhouse Wastew aters with Nessler's Reagent: Effect of Different Preatreatment Methods, Adv Mat Res, 955-959, 2014, p. 1241-1244

4.CONNERTY H.V., BRIGGS A.R., EATON E.H., Determination of Preformed Urinary Ammonia (Nitrogen) by Means of Direct Nesslerization, Am J Clin Pathol, 28, nr. 6, 1956, p. 634-638

5.MURAMATSU K., Direct colorimetric Method for the Determination of Free Ammonia in Blood, Agr. Biol. Chem., 31, nr. 3, 1967, p.301-308 6.J EONG H., PARK J., KIM H., Determination of $\mathrm{NH}_{4}^{+}$in Environmental Water with Interfering Substances Using the Modified Nessler Method, Journal of Chemistry Vol. 2013, Article ID 359217, 9 pages, http:// dx.doi.org/10.1155/2013/359217

7.KRUG F.J ., HANSEN E.H., RUZYCKA J ., Determination of ammonia in low concentrations with Nessler's reagent by flow injection analysis, Analyst, 104, nr. 1234, 1979, p.47-54

8.*** http://www.creeaza.com/referate/chimie/DETERMINAREAAMONIACULUI-DIN A812.php

9.GASTON Charlot, Les Methods de la Chimie Analitique, Masson et $\mathrm{C}^{\mathrm{IE}}$, Editeurs, Paris, 1966, p.612-613

10.KOROLEFF Folke, Direct spectrophotometric determination of ammonia in precipitation, Tellus, XVIII, nr. 2, 1966, p.562-565

Manuscript received: 15.08 .2018 